\title{
ODDZIAŁYWANIE WYROKÓW WOJEWÓDZKICH SĄDÓW ADMINISTRACYJNYCH W CZASIE - WYBRANE ZAGADNIENIA
}

1. Celem opracowania jest analiza skuteczności wyroków sądów administracyjnych rozpatrywana z punktu widzenia ich oddziaływania w czasie w odniesieniu do wybranych form działania organów administracji skarbowej oraz w odniesieniu do ich bezczynności. Zakresem referatu objęto formy działania administracji skarbowej związane z realizowaniem zobowiązań podatkowych na gruncie ordynacji podatko$w_{\text {wej}}{ }^{1}$. Do kategorii tej zaliczyć należy decyzje i postanowienia, inne niż decyzje i postanowienia akty lub czynności z zakresu administracji publicznej dotyczące uprawnień lub obowiązków wynikających z przepisów prawa oraz pisemne interpretacje przepisów prawa podatkowego wydawane w indywidualnych sprawach.

Ograniczenie rozważań ujętych w referacie tylko do przedstawienia skuteczności oddziaływania w czasie wyroków wojewódzkich sądów administracyjnych na wskazane formy działania administracji skarbowej wynika z dwóch zasadniczych powodów. Po pierwsze, podyktowane jest specyfiką procesu realizacji zobowiązań podatkowych; po drugie, wiąże się ze szczególną pozycją organów administracji skarbowej w procesie realizowania tych zobowiązań.

2. Ocena oddziaływania wyroków sądów administracyjnych w czasie i wywierane przez nie określone skutki na podejmowane przez organy administracji skarbowej akty, interpretacje i czynności, wymaga uwzględnienia przede wszystkim kasacyjnego, z niewielkimi wyjątkami, charakteru orzeczeń sądów administracyjnych. Zadaniem sądu administracyjnego nie jest konkretyzacja norm prawa materialnego, co jest domeną organów administracji publicznej. Sąd ten kontroluje zgodność z prawem procesu konkretyzacji normy dokonywanego przez administrację publiczną, w tym także administrację skarbową. Kontrola sądu administracyjnego obejmu-

1 Ustawa z dnia 29 sierpnia 1997 r. - Ordynacja podatkowa, tekst jedn. Dz.U. z 2005 r. Nr 8, poz. 60 z późn. zm., dalej: o.p. 
je zatem kwestie związane z procesem stosowania prawa w szeroko pojmowanym postępowaniu podatkowym, a więc to, czy organ administracyjny dokonał prawidłowych ustaleń co do obowiązywania określonej normy prawnej, czy normę tę właściwe wyinterpretował oraz czy nie naruszył zasad ustalenia określonych faktów za udowodnione. Uwzględnienie przez sąd skargi wiąże się z koniecznością wyeliminowania $z$ obrotu prawnego zaskarżonego aktu prawnego bądź interpretacji lub też stwierdzenie bezskuteczności zaskarżonej czynności. Z kolei następstwem nieuwzględnienia skargi jest jej oddalenie.

Oddziaływanie w czasie orzeczeń sądów administracyjnych wiąże się przede wszystkim z ich skutecznością prawną. Skuteczność prawna polega na tym, że określonemu stanowi rzeczy przypisuje się normatywnie określone następstwa prawne ${ }^{2}$. Następstwa te zachodzą w określonej przestrzeni (przedmiocie), ale także i w czasie. W najprostszym ujęciu oddziaływanie wyroku w czasie oznacza wywieranie skutków prawnych w odniesieniu do zaskarżonego działania wstecz (ex tunc) bądź też od momentu jego ogłoszenia (ex nunc). Poprzez wpływanie na działanie lub bezczynność administracji skarbowej wyrok sądu administracyjnego wywiera także skutki na sytuację prawną zarówno samego organu administracji skarbowej, jak też adresata jego działań. Skutki prawne orzeczenia sądu administracyjnego mogą oddziaływać zarówno na sytuację procesową jak też materialnoprawną wskazanych podmiotów.

W przypadku wyroków uwzględniających skargę ich oddziaływanie w czasie uzależnione jest od rodzaju sankcji prowadzącej do obalenia zaskarżonego aktu, interpretacji lub czynności, przewidzianej w ustawie o postępowaniu przed sądami administracyjnymi ${ }^{3}$. Rodzaj zastosowanej sankcji uzależniony jest od formy działania organu administracji publicznej podlegającej kontroli sądu administracyjnego. Jedynie w przypadku nieuwzględnienia skargi przewidziano wspólne rozwiązanie. Zgodnie bowiem $z$ art. 151 p.p.s.a. w razie nieuwzględnienia skargi sąd skargę oddala.

Ze względu na to, że ustawodawca w zasadzie nie wyposażył sądu administracyjnego w instrumenty umożliwiające bezpośrednią konkretyzację sytuacji prawnej podmiotów administrowanych, w przypadku uwzględnienia skargi nieodzowne stało się wprowadzenie instytucji związania organu administracyjnego zapatrywaniami sądu administracyjnego i prawnego wpływania (oddziaływania) orzecznictwa sądu na działania administracji publicznej zarówno przeszłe, jak i przyszłe. Zgodnie z art. 153 p.p.s.a. ocena prawna i wskazania co do dalszego postępowania wyrażone w orzeczeniu sądu wiążą w sprawie ten sąd oraz organ, którego działanie lub bez- 
czynność było przedmiotem zaskarżenia. Do przeszłości, czyli do dotychczasowego postępowania organów w sprawie - choć nie wyłącznie - odnosi się ocena prawna. Sąd, badając zgodność z prawem zaskarżonego aktu, interpretacji lub czynności organu administracji skarbowej, bierze pod uwagę stan faktyczny i prawny sprawy istniejący w dacie jego podjęcia, czyli w przeszłości. Ocena prawna oddziałuje jednak w pewnym zakresie także na przyszłość. Pozostaje w ścisłym związku ze wskazaniami co do dalszego postępowania ${ }^{4}$. Natomiast wskazania co do dalszego postępowania odnoszą się wyłącznie do przyszłości. Wytyczają bowiem sposób postępowania organu podatkowego w postępowaniu podatkowym, które będzie prowadzone w przyszłości.

3. W odniesieniu do decyzji i postanowień wydanych w postępowaniu podatkowym katalog rodzajów wyroków uwzględniających skargę zawiera art. $145 \S 1$ p.p.s.a. Obalenie wskazanych aktów organów administracji skarbowej następuje poprzez: 1) uchylenie decyzji lub postanowienia w całości albo w części, 2) stwierdzenie nieważności decyzji lub postanowienia w całości lub w części.

Ustawodawca nawiązuje do teorii gradacji wad indywidualnych aktów administracyjnych, zgodnie z którą najcięższe wady są podstawą stwierdzenia nieważności aktu, co niweczy jego skutki z mocą wsteczną, natomiast wady ciężkie dają podstawę do obalenia aktu ze skutkiem ex nunc, co następuje poprzez uchylenie danego $a^{2} u^{5}$. Stwierdzenie nieważności decyzji podatkowej lub postanowienia wydanego w postępowaniu podatkowym daje podstawę do potraktowania takich aktów prawnych, tak jakby nigdy nie funkcjonowały w obrocie prawnym. W przypadku stwierdzenia nieważności decyzji lub też postanowienia mamy do czynienia z wyrokiem o charakterze deklaratoryjnym ${ }^{6}$. Wyrok sądu w takim przypadku potwierdza to, że zaskarżona decyzja lub postanowienie nie mogły wywołać skutków prawnych od samego początku, czyli od dnia wejścia do obrotu prawnego. Wskazuje się bowiem, że decyzja nieważna nie ma mocy obowiązującej, przeto w ogóle nie wiąże adresata i nie jest skuteczna erga omnes. W takiej sytuacji wyrok sądu wywołuje skutek materialnoprawny w postaci zniesienia z mocą wsteczną (ex tunc) wszystkich następstw nieważnej decyzji ${ }^{7}$.

W sytuacji natomiast, gdy sąd uchyla zaskarżony akt administracyjny, orzeczenie sądu wywołuje skutek taki, że uchylona decyzja (postanowienie) traci moc obo-

4 Zob. T. Woś, Związki postępowania administracyjnego i sądowo-administracyjnego, Zeszyty Naukowe UJ 1989, CMXLIX, z. 134, s. 177.

5 B. Adamiak, J. Borkowski, Metodyka sędziego w sprawach administracyjnych, Warszawa 2009, s. 29.

6 por. L. Żukowski, R. Sawuła, Postępowanie administracyjne i postępowanie przed Naczelnym Sądem Administracyjnym, Warszawa 2002, s. 276 i n.; wyrok NSA z dnia 8 kwietnia 2008 r., sygn. akt II FSK 135/08, LEX nr 506487.

7 Zob. Z. Kmieciak, J.P. Tarno, Postępowanie administracyjne oraz postępowanie przed Naczelnym Sądem Administracyjnym (w świetle orzecznictwa NSA), Warszawa 1988, s. 190. 
wiązującą w chwili uchylenia, czyli ex nunc, co ma związek z konstytutywnym charakterem wyroku sądu. Wskazuje się, że skutek materialnoprawny takiego wyroku polega na tym, że znosi on następstwa uchylonego aktu ex nunc, czyli od chwili jego wydania $^{8}$. Oznacza to, że zaskarżone akty indywidualne od daty ich doręczenia stronie do daty obalenia wyrokiem sądu muszą być traktowane jako istniejące i wiążące.

Niezależnie od wskazanych poglądów, z którymi należy się zgodzić, warto jednak zwrócić uwagę na to, że uchylenie przez sąd indywidualnego aktu administracyjnego wywołuje w pewnym zakresie także skutki o charakterze wstecznym. W pierwszej kolejności można zająć stanowisko, że każdy wyrok uwzględniający skargę i obalający zaskarżony indywidualny akt administracyjny, niezależnie od tego, czy stwierdza nieważność danego aktu czy tylko uchyla taki akt, działa ex tunc, skoro wywiera wpływ na rozstrzygnięcie administracji skarbowej zawsze w stosunku do wyroku sądu administracyjnego uprzednie. W dalszej kolejności można dojść do wniosku, że działanie wyroku uchylającego decyzję podatkową lub postanowienie obejmuje w czasie okres przed wydaniem zaskarżonej decyzji lub postanowienia. Wywołuje bowiem powrót do takiej sytuacji procesowej, a nawet materialnoprawnej, która istniała przed wydaniem decyzji podatkowej lub postanowienia, poddanych kontroli sądu administracyjnego. Należy zwrócić uwagę, że wskazaną argumentację wykorzystuje się na potwierdzenie działania wyroku sądu administracyjnego ex tunc, co jednak nie jest przekonujące ${ }^{9}$.

Oddziaływanie wyroku sądu administracyjnego w odniesieniu do okresu sprzed wydania zaskarżonego aktu administracyjnego można łatwo dostrzec na gruncie stosunków podatkowoprawnych. Niewątpliwie na sytuację prawną podmiotu biernego stosunku prawnopodatkowego wpływają działania organów administracji skarbowej oraz sądów administracyjnych, podejmowane $\mathrm{w}$ ramach procesu realizowania zobowiązania podatkowego, który nieodzownie wiąże się ze stosowaniem prawa. Zaznaczyć jednak należy, że jeżeli chodzi o prawo podatkowe, to jego stosowanie następuje w dwóch etapach. W pierwszym etapie podmiotami stosującymi to prawo są określone podmioty bierne stosunku prawnopodatkowego, a w szczególności podatnicy i płatnicy. Z kolei w drugim etapie mamy do czynienia z klasycznym stosowaniem prawa, albowiem stosowanie prawa jest tu domeną organów administracji skarbowej i - co jest istotne - także sądów ${ }^{10}$. Stanowisko dotyczące stosowania prawa materialnego przez sądy administracyjne budziło szereg wattpliwości w doktrynie oraz w orzecznictwie. Wskazywano bowiem, że normy prawa materialnego sto-

\footnotetext{
$8 \quad$ Zob. Z. Kmieciak, J.P. Tarno, Postępowanie administracyjne oraz postępowanie przed Naczelnym Sądem Administracyjnym (w świetle orzecznictwa NSA), Warszawa 1988, s. 191; wyrok NSA z dnia 8 kwietnia 2008 r., II FSK 135/08, LEX nr 506487.

9 Zob. wyrok WSA w Warszawie z dnia 10 stycznia 2007 r., II SA/Wa 999/06, niepubl.

10 R. Mastalski, Stosowanie prawa podatkowego, Warszawa 2008, s. 39 i n.
} 
suje organ administracji publicznej ${ }^{11}$. W najnowszym orzecznictwie Naczelny Sąd Administracyjny zają stanowisko, iż stosowanie przepisu prawa materialnego przez sąd administracyjny polega na uczynieniu takiego przepisu wzorcem kontroli legalności decyzji administracyjnej. Jest to zatem tzw. „weryfikacyjne” stosowanie normy prawnej ${ }^{12}$.

Pewne znamiona wstecznego oddziaływania wyroków sądów administracyjnych uchylających zaskarżony akt indywidualny administracji skarbowej dostrzec nożna w przypadku kontroli deklaratoryjnych decyzji podatkowych związanych $\mathrm{z}$ weryfikacją samoobliczenia podatku. W prawie podatkowym skutki prawne wywoływane są bezpośrednio, czyli z mocy samego prawa na podstawie normy generalno-abstrakcyjnej albo też pośrednio w wyniku konkretyzacji takiej normy. W tych dwóch przypadkach, aby skutek prawny mógł wystapić, konieczne jest zaistnienie w rzeczywistości stanu faktycznego odpowiadającego zakresowi stosowania normy abstrakcyjnej. W przypadku skutku prawnego wynikającego z mocy prawa, który normatywnie istnieje od chwili wypełnienia stanu faktycznego normy, niezbędne jest potwierdzenie tego faktu. W odniesieniu do skutku prawnego w postaci powstania z mocy prawa zobowiązania podatkowego potwierdzenie tego faktu następuje najczęściej w deklaracji składanej przez podatnika. W następstwie zaś weryfikacji takiej deklaracji i podważania danych z niej wynikających nieodzowne staje się autorytatywne potwierdzenie tego faktu w drodze decyzji określającej wysokość zobowiązania podatkowego, której przypisuje się cechy deklaratoryjności. Zgodnie bowiem $\mathrm{z}$ art. $21 \S 2$ o.p. jeżeli przepisy prawa podatkowego nakładają na podatnika obowiązek złożenia deklaracji, a zobowiązanie podatkowe powstaje z dniem zaistnienia zdarzenia, $z$ którym ustawa podatkowa wiąże powstanie takiego zobowiązania, podatek wykazany $\mathrm{w}$ deklaracji jest podatkiem do zapłaty, z zastrzeżeniem art. $21 \S 3$ o.p. Ten ostatni zaś stanowi, że jeżeli w postępowaniu podatkowym organ podatkowy stwierdzi, że podatnik, mimo ciążącego na nim obowiązku, nie zapłacił w całości lub w części podatku, nie złożył deklaracji albo że wysokość zobowiązania podatkowego jest inna niż wykazana w deklaracji, organ podatkowy wydaje decyzję, w której określa wysokość zobowiązania podatkowego. Akt określający wysokość zobowiązania podatkowego nie tworzy skutków prawnych, gdyż wynikają one z mocy samego prawa, lecz w sposób wiążący je potwierdza. Oznacza to, że podatkowa decyzja deklaratoryjna działa z mocą ex tunc, czyli z mocą wsteczna, od chwili, gdy zaistniało pewne zdarzenie powodujące powstanie stosunku prawnego $\mathrm{z}$ mocy prawa ${ }^{13}$. Niezbędność wydania takiego aktu wynika z potrzeb związanych

\footnotetext{
11 Zob. np. Z. Kmieciak, Podstawy skargi kasacyjnej do Naczelnego Sądu Administracyjnego, „Państwo i Prawo” 2005, z. 1, s. 18 i n.; H. Knysiak-Molczyk, (w:) T. Woś, H. Knysiak-Molczyk, M. Romańska, Prawo o postępowaniu przed sądami administracyjnymi. Komentarz, red. T. Woś, Warszawa 2005, s. 540; wyrok NSA z dnia 27 października 2004 r., FSK 116/04, LEX nr 147655. 
z etapem stosowania prawa i realizowania zobowiązań podatkowych. O ile bowiem zobowiązania te już istnieją, co oznacza, że funkcjonują określone skutki prawne, nie ma jednak obiektywnie uchwytnych podstaw do ich realizacji.

Z kolei decyzja ustalająca wysokość zobowiązania podatkowego, której przypisuje się charakter konstytutywny, sama tworzy, zmienia lub znosi skutki prawne, które norma abstrakcyjna określa jedynie ogólnie i potencjalnie. Decyzja taka zatem konkretyzuje te skutki, precyzując zakres i treść stosunku materialnoprawnego. W sferze stosunków podatkowowprawnych akt taki wywołuje powstanie zobowiązania podatkowego. Decyzja taka działa z mocą ex nunc, czyli wywołuje skutki prawne z chwilą jej doręczenia.

W literaturze wskazuje się, że nie jest możliwy ścisły podział decyzji na deklaratoryjne i konstytutywne ${ }^{14}$. Ponadto podkreśla się, że nabycia praw z decyzji organów skarbowych nie można wiązać z ich podziałem na decyzje konstytutywne i deklaratoryjne $z$ uwagi na zawodność tego podziału ${ }^{15}$. Można wyodrębnić decyzje wykazujące elementy konstytutywne oraz deklaratoryjne. Przykładem takiego aktu prawnego jest decyzja w przedmiocie opodatkowania dochodów z nieujawnionych źródeł przychodów lub nieznajdujących pokrycia w ujawnionych źródłach ${ }^{16}$.

Potwierdzając stanowisko, iż wyrok sądu administracyjnego uchylający decyzję podatkową nie eliminuje takiego aktu z mocą wsteczną, albowiem wskazany skutek wywiera jedynie stwierdzenie nieważności decyzji, to jednak w odniesieniu do sytuacji podatkowoprawnej adresata decyzji w pewnym zakresie może wywierać skutek wsteczny, obejmujący okres sprzed wydania zaskarżonego aktu. Jest to widoczne zwłaszcza w sytuacji uchylenia decyzji określającej wysokość zobowiązania podatkowego. Uchylenie lub stwierdzenie nieważności takiej decyzji, podobnie zresztą jak decyzji ustalającej wysokość zobowiązania podatkowego, może wiązać się z koniecznością zwrotu nadpłaty. Ponadto, jeżeli podatnik oprócz podatku wynikającego z decyzji określającej zobowiązanie podatkowe uiścił także odsetki od zaległości podatkowej, także to świadczenie podlega zwrotowi. Unicestwienie decyzji określającej wysokość zobowiązania podatkowego powoduje, że ponownie podatkowoprawna sytuacja podatnika znajduje odzwierciedlenie w złożonej deklaracji podatkowej. Obalenie takiej decyzji przywraca wynikające z art. $21 \S 2$ o.p. domniemanie zgodności z prawem deklaracji podatkowej. Wskazane przykłady są niewątpliwie przejawem powrotu do sytuacji, która miała miejsce przed wydaniem

14 M. Masternak, Istota i rodzaje decyzji podatkowych, „Kwartalnik Prawa Podatkowego” 1999, nr 3-4, s. 118; H. Dzwonkowski, Powstawanie zobowiązań podatkowych a charakter prawny decyzji wymiarowych, „Monitor Podatkowy" 2003, nr 7, s. 22.

15 J. Borkowski, Nabycie praw z decyzji organów podatkowych. Glosa do wyroku NSA z dnia 31 sierpnia 1995 r., SA/Po 313-314/95, „Glosa” 1996, nr 12, s. 15.

16 H. Dzwonkowski, Powstawanie zobowiązań podatkowych a charakter prawny decyzji wymiarowych, „Monitor Podatkowy” 2003, nr 7, s. 23 oraz P. Pietrasz, Opodatkowanie dochodów nieujawnionych, Warszawa 2007, s. $157 \mathrm{in}$. 
zaskarżonej decyzji. Niemniej jednak z uwagi na związanie organu administracyjnego oceną prawną i wskazaniami co do dalszego postępowania wyrażonymi w orzeczeniu sądu stan ten nie jest identyczny z tym, który istniał przed wydaniem uchylonej decyzji.

Doniosłym przykładem objęcia działaniem wstecz wyroku stwierdzającego nieważność decyzji podatkowej jest fakt, iż następstwa w postaci przerwania biegu terminu przedawnienia zgodnie $\mathrm{z}$ art. $70 \S 4$ o.p. nie powoduje zastosowanie środka egzekucyjnego na podstawie tytułu wykonawczego wydanego na podstawie decyzji, którą następnie wzruszono w trybie stwierdzenia nieważności ${ }^{17}$. Skutku takiego nie wywołuje natomiast uchylenie decyzji podatkowej, na podstawie której wydano tytuł wykonawczy ${ }^{18}$. Podobne, odmienne skutki w czasie wywołuje uchylenie i stwierdzenie nieważności postanowienia w przedmiocie nadania rygoru natychmiastowej wykonalności nieostatecznej decyzji podatkowej ${ }^{19}$.

Skutki procesowe uchylenia decyzji podatkowej, a także stwierdzenia nieważności takiego aktu zasadniczo nie niweczą czynności organu administracji skarbowej podjętych w toku postępowania. Obowiązek dokonania po raz drugi przeprowadzonych uprzednio czynności procesowych będzie spoczywał na organie podatkowym tylko w przypadku, gdy sąd administracyjny uzna za wadliwe całe postępowanie poprzedzające wydanie uchylonego rozstrzygnięcia. $Z$ sytuacją taką możemy mieć do czynienia w niektórych przypadkach nieważności decyzji, np. w przypadku wydania decyzji z naruszeniem przepisów o właściwości lub skierowania decyzji do osoby niebędącej stroną w sprawie. W innych przypadkach powtórzeniu będą podlegały tyko czynności uznane przez sąd za dokonane nieprawidłowo, co przyczynito się do uchylenia zaskarżonego aktu prawnego ${ }^{20}$.

Podsumowując ten fragment referatu, można dojść do wniosku, że w przypadku stwierdzenia nieważności decyzji lub postanowienia, z uwagi na skutek ex tunc sankcji nieważności aktu administracyjnego, wskazane akty prawne uznaje się za niebyłe. Skutek wsteczny odnosi się do kwestii zasadniczej, a mianowicie bytu prawnego analizowanych form działania administracji skarbowej. $Z$ kolei uchylenie decyzji lub postanowienia działa pro futuro i oznacza, że akty te od daty ich doręczenia stronie do daty obalenia wyrokiem sądu muszą być traktowane jako istniejące i wiążące. Niemniej jednak zniesienie następstw tych aktów i powrót do sytuacji istniejącej przed wydaniem uchylonych decyzji lub postanowień wykazuje określone cechy działania wstecz. Skutki te nie dotyczą jednak bytu decyzji lub postano-

17 Wyrok NSA z dnia 26 kwietnia 2002 r., I SA/Lu 685/00, LEX nr 76007.

18 Wyroki NSA z dnia 18 października 2005 r., II FSK 351/05, LEX nr 193470 oraz z dnia 14 grudnia 2005 r., II FSK 52/05, LEX nr 190348.

19 Zob. P. Pietrasz, Rygor natychmiastowej wykonalności a przerwana biegu terminu przedawnienia zobowiązania podatkowego, „Przegląd Podatkowy” 2010, nr 4, s. 44 i n.

20 T. Woś, (w:) Prawo o postępowaniu przed sądami administracyjnymi. Komentarz, red. T. Woś, Warszawa 2005, s. 476 . 
wienia, ale odnoszą się do sytuacji podatkowoprawnej podmiotów stosunku prawnego.

4. Kolejną sankcją przewidzianą w art. $145 \S 1$ p.p.s.a., która nie wiąże się jednak z wyeliminowaniem z obrotu prawnego zaskarżonej decyzji lub postanowienia, jest stwierdzenie wydania decyzji lub postanowienia z naruszeniem prawa, jeżeli zachodzą przyczyny określone w kodeksie postępowania administracyjnego lub co jest istotne $\mathrm{z}$ perspektywy oceny aktów podjętych w postępowaniu podatkowym - w innych przepisach. Sąd administracyjny nie wyklucza zatem z obrotu prawnego zaskarżonego aktu prawnego, zaś w to miejsce stwierdza wydanie decyzji lub postanowienia $\mathrm{z}$ naruszeniem prawa, w sytuacji wystapienia przesłanek negatywnych przy stosowaniu sankcji nieważności decyzji (art. 247 § 2 i 3 o.p.), bądź przesłanek negatywnych uchylenia decyzji po wznowieniu postępowania (art. $245 \S 2$ o.p.). Stwierdzenie przez sąd wydania aktu administracyjnego z naruszeniem prawa ma charakter deklaratoryjny. Sąd, nie mogąc zastosować sankcji powodującej wyeliminowanie zaskarżonego aktu z obrotu prawnego, jedynie potwierdza jego kwalifikowane wady. Skoro jednak sąd stwierdza istnienie wad powstałych wcześniej, jeszcze przed wydaniem wyroku sądu, można dojść do wniosku, że wyrok taki działa w określonym zakresie ex tunc, czyli z mocą wsteczną. Zasadniczym skutkiem takiego wyroku wywoływanym na przyszłość (ex nunc) jest możliwość dochodzenia odszkodowania przez stronę, która poniosła szkodę w następstwie wydania decyzji dotkniętej jedną $\mathrm{z}$ wad wymienionych $\mathrm{w}$ art. $247 \S 1$ o.p. oraz w art. $240 \S 1$ o.p. Rozstrzygniecie sądu w tym przedmiocie pozwoli bowiem uzyskać odszkodowanie na podstawie przepisów prawa cywilnego. Zgodnie bowiem z art. $4171 \S 2$ kodeksu cywilnego, ${ }^{21}$ jeżeli szkoda została wyrządzona przez wydanie prawomocnego orzeczenia lub ostatecznej decyzji, jej naprawienia można żądać po stwierdzeniu we właściwym postępowaniu ich niezgodności z prawem.

5. W przypadku uwzględnienia skargi na określone w art. $3 \S 2$ pkt 4 p.p.s.a. akty lub czynności z zakresu administracji publicznej dotyczące uprawnień lub obowiązków wynikających z przepisów prawa inne niż decyzje, postanowienia wydane w postępowaniu podatkowym, na które służy zażalenie albo kończące postępowanie, a także na postanowienia rozstrzygające sprawę co do istoty oraz postanowienia wydane w postępowaniu egzekucyjnym i zabezpieczającym, na które służy zażalenie, sąd zgodnie z art. $146 \S 1$ p.p.s.a. uchyla ten akt albo stwierdza bezskuteczność czynności. Ponadto za sprawą art. $146 \S 2$ p.p.s.a. w takich sprawach sąd został wyposażony w możliwość orzeczenia co do istoty, gdyż może w wyroku uznać uprawnienie lub obowiązek wynikające z przepisów prawa. Również uwzględnie- 
nie skargi na pisemną interpretację przepisów prawa podatkowego wydawaną w indywidualnej sprawie wiąże się z uchyleniem tej formy działania organu administracji skarbowej. W takim przypadku sąd w wyroku może także uznać uprawnienie lub obowiązek wynikające z przepisów prawa (art. 146 § 1 i 2 p.p.s.a.).

Mając na uwadze przedstawione rozwiązania, należy zwrócić uwagę, iż w sytuacji uwzględnienia skargi na akty z zakresu administracji publicznej, dotyczące uprawnień lub obowiązków wynikających z przepisów prawa oraz na pisemną interpretację przepisów prawa podatkowego, sąd uchyla te formy działania administracji publicznej. Natomiast w przypadku uwzględnienia skargi na czynności z zakresu administracji publicznej, dotyczące uprawnień lub obowiązków wynikających z przepisów prawa, sąd stwierdza bezskuteczność tych czynności. Ponadto w odniesieniu do tych trzech rodzajów form działania administracji (aktów, czynności i indywidualnych interpretacji) w przypadku uwzględnienia skargi sąd może uznać uprawnienie lub obowiązek wynikające z przepisów prawa.

Wzruszenie aktów z zakresu administracji publicznej, dotyczących uprawnień lub obowiązków wynikających z przepisów prawa, powoduje skutek prawny pozbawienia mocy obowiązującej tych form działania administracji publicznej i zdolności wywołania ich na przyszłość. Wywołane zaś skutki prawne pozostają w mocy ${ }^{22}$. W zasadzie analogiczne skutki należy przypisać uchyleniu pisemnej interpretacji przepisów prawa podatkowego. Oznacza to zatem, że uchylony akt lub interpretacja traci moc obowiązującą w chwili uchylenia, czyli ex nunc, co ma związek z konstytutywnym charakterem takiego orzeczenia.

Podobnie jednak jak w przypadku wyroku uchylającego decyzję lub postanowienie, należy dostrzec elementy deklaratoryjne orzeczenia uchylającego formy działania administracji określone w art. $3 \S 2$ pkt 4 i 4 a p.p.s.a. Skoro bowiem wyrok taki wywiera wpływ na akty administracji skarbowej oraz na pisemne interpretacje wyprzedzające w czasie wydanie tego wyroku, to w pewnym sensie orzeczenie sądu działa w odniesieniu do przeszłości. Działanie wyroku wywołuje powrót do sytuacji prawnej istniejącej przed wydaniem aktu lub interpretacji indywidualnej, które poddano następnie kontroli sądu administracyjnego.

Jak wskazuje się w literaturze, w przeciwieństwie do aktów administracyjnych, czynności z zakresu administracji publicznej dotyczące uprawnień lub obowiązków wynikających z przepisów prawa nie kształtują normy jednostkowej i konkretnej będącej trwałym elementem obowiązującego porządku prawnego. $\mathrm{O}$ ile podjęcie aktu administracyjnego jest zawsze przejawem stosowania prawa, to czynności służą jedynie jego wykonaniu, rozumianemu jako doprowadzenie do rzeczywistej rea- 
lizacji dyspozycji norm prawnych ${ }^{23}$. Konsekwencją takiego stanu rzeczy jest rodzaj sankcji, która ma zastosowanie w przypadku uznania za zasadną skargi na czynność z zakresu administracji publicznej dotyczącą uprawnień lub obowiązków wynikających z przepisów prawa, która sprowadza się do orzeczenia o jej bezskuteczności.

Bezskuteczność czynności, o której mowa w art. 3 § 2 pkt 4 p.p.s.a., oznacza, że jej dokonanie od chwili jej wykonania nie wywołało skutku prawnego, a zatem nie mogło również wywołać następnych skutków prawnych w zakresie sytuacji jednostki. Tym samym bezskuteczność wywiera skutki podobne do tych, jakie wywołuje nieważność. Zachodzi zatem zrównanie następstw prawnych nieważności i bezskuteczności ${ }^{24}$. Wyrok sądu stwierdzający bezskuteczność czynności z zakresu administracji publicznej dotyczącej uprawnień lub obowiązków wynikających z przepisów prawa ma więc charakter deklaratoryjny i w odniesieniu do tej formy działania administracji publicznej działa z mocą wsteczną. Wyrok sądu w takim przypadku potwierdza to, że zaskarżona czynność nie mogła wywołać skutków prawnych od samego początku, czyli od dnia jej dokonania.

Uznanie przez sąd uprawnienia lub obowiązku, które wynikają z przepisów prawa, oznacza, że w takiej sytuacji wyrok potwierdza określone skutki prawne, które wywołane są z mocy samego prawa. Sąd wydaje zatem wyrok, w którym potwierdzone zostaje to, co wynika pośrednio lub bezpośrednio z przepisów prawa. Orzeczenie sądu ma w takiej sytuacji charakter deklaratoryjny i działa ze skutkiem ex $\operatorname{tunc}^{25}$.

6. Zgodnie $\mathrm{z}$ art. 149 p.p.s.a. sąd, uwzględniając skargę na bezczynność organów w sprawach określonych w art. $3 \S 2$ pkt $1-4 a$ p.p.s.a., czyli między innymi w sprawach, w których wydawane są decyzje, postanowienia, na które służy zażalenie albo kończące postępowanie, a także postanowienia rozstrzygające sprawę co do istoty oraz pisemne interpretacje przepisów prawa podatkowego wydawane w indywidualnej sprawie, zobowiazuje organ do wydania w określonym terminie aktu lub interpretacji lub dokonania czynności, lub stwierdzenia albo uznania uprawnienia lub obowiązku wynikających z przepisów prawa. Nie można mieć wątpliwości co do tego, że wyrok taki wywołuje skutki prawne ex nunc, czyli skutki wpływające na przyszłą sytuację prawną zarówno skarżącego, jak też organu administracji publicznej. Nie można jednak tracić z pola widzenia wywoływania, w sposób pośredni, skutków działających wstecz. Przykładowo wskazać należy, że jeżeli skarga na

23 Z. Kmieciak, Glosa do wyroku WSA w Gdańsku z dnia 19 grudnia 2006 r., III SA/Gd 440/06, OSP 2007, z. 10, poz. 115 , s. 724 .

24 Zob. szerzej B. Adamiak, J. Borkowski, Metodyka sędziego w sprawach administracyjnych, Warszawa 2009 , s. 149.

25 Zob. też J. Jednrośka, J. Jedndrośka, Nowy model sądownictwa administracyjnego w Polsce, „Państwo i Prawo” 1996, z. 8-9, s. 21. 
bezczynność dotyczy postępowania organu administracji skarbowej, w którym ma zastać wydana decyzja podatkowa o charakterze deklaratoryjnym, to skuteczność wyroku zobowiązującego organ do wydania w określonym terminie takiej decyzji odnosi się do przeszłości.

Istotnym skutkiem wyroku uwzględniającego skargę na bezczynność organu administracji publicznej wywoływanym na przyszłość (ex nunc) jest możliwość dochodzenia odszkodowania przez stronę, która poniosła szkodę w następstwie bezczynności organu. Zgodnie bowiem z art. $4171 \S 3$ kc., jeżeli szkoda została wyrządzona przez niewydanie orzeczenia lub decyzji, gdy obowiązek ich wydania przewiduje przepis prawa, jej naprawienia można żądać po stwierdzeniu we właściwym postępowaniu niezgodności z prawem niewydania orzeczenia lub decyzji, chyba że przepisy odrębne stanowią inaczej.

7. Stwierdzenie przez sąd administracyjny, że zaskarżony akt, interpretacja lub czynność są zgodne z prawem, powoduje nieuwzględnienie skargi ${ }^{26}$. W takim przypadku sąd oddala skargę. Oddalenie skargi jest wyrazem potwierdzenia przez sąd zgodności z prawem zaskarżonego aktu, interpretacji lub czynności. Wyrok sądu ma tu charakter deklaratoryjny. Poddany kontroli sądu akt oraz interpretację należy uznać za zgodne z prawem od daty ich wydania, zaś czynność od daty jej dokonania. W konsekwencji można zająć stanowisko, iż wyrok oddalający skargę wywołuje skutki prawne ex tunc.

8. Nasuwa się wniosek, iż skuteczność oddziaływania w czasie wyroków wojewódzkich sądów administracyjnych uzależniona jest od tego, czy sąd skargę uwzględnił czy też oddalił. W przypadku zaś uwzględniania skargi zależy od rodzaju sankcji prowadzącej do obalenia zaskarżonego aktu, interpretacji lub czynności, przewidzianej w ustawie o postępowaniu przed sądami administracyjnymi. Ponadto należy uwzględnić i odróżnić kwestię oddziaływania wyroku na zaskarżone działanie lub bezczynność organu administracji skarbowej od oddziaływania - w sposób w pewnym sensie pośredni - na sytuację podatkowprawną (procesową i materialną) podmiotów stosunku podatkowoprawnego.

W najprostszym ujęciu oddziaływanie wyroku w czasie oznacza wywieranie skutków prawnych w odniesieniu do zaskarżonego aktu, interpretacji lub czynności wstecz (ex tunc) bądź też od momentu jego ogłoszenia (ex nunc). Poprzez oddziaływanie na działanie lub bezczynność administracji skarbowej wyrok sądu administracyjnego wywiera także skutki na sytuację prawną zarówno organu administracji skarbowej, jak też adresata działania tego organu. Skutki prawne orzeczenia sądu 
administracyjnego mogą oddziaływać zarówno na sytuację procesoprawną, jak też materialnoprawną wskazanych podmiotów.

Oceniając skuteczność oddziaływania wyroku sądu administracyjnego w czasie z perspektywy sytuacji prawnej podmiotu stosunku podatkowoprawnego istotne staje się uwzględnienie charakteru formy działania organu administracji skarbowej poddanej kontroli sądowej. Wyrok sądu administracyjnego dotyczący działania organu administracji skarbowej o charakterze deklaratoryjnym - siłą rzeczy - w sposób pośredni wywołuje skutki wstecz. 


\title{
THE IMPACT OF REGIONAL ADMINISTRATIVE COURTS JUDGMENTS AT THE TIME - SELECTED ISSUES
}

\author{
SUMMARY
}

The aim of this paper is to analyze the effectiveness of administrative courts judgments considered in terms of their impact over time for selected forms of action and inaction (inactivity) of tax authorities relating to the implementation of tax liability on the basis of Tax Law. Furthermore, this paper analyzed the impact of such judgments in time for the parties to respect the legal situation for tax purposes.

In the simplest terms, the impact of judgment at the time means to have an effect on the legal consequences in respect of the contested act, interpretation or action back (retroactive - ex tunc) or from the time of its announcement (ex nunc). By influencing the action or inaction (inactivity) of tax administration the judgment of administrative court has also impact on the legal situation (procedural and substantive) for both the authority as well as the recipient of that authority.

The effectiveness of the impact at the time of the judgments of provincial administrative courts depends largely on whether the court upheld the complaint or dismiss it. In case of taking into account the effectiveness depends on the type of penalties leading to the overthrow of the contested act, interpretation or actions, provided for in the Law on proceedings before administrative courts. We should also take into account and distinguish the impact point on appeal challenged action or inaction (inactivity) of the tax authorities from the impact - in a certain sense indirect - on the tax law situation (procedural and substantive) of the entity. 